\title{
Diseases Resulting from Trematode Infestations in Oreochromis niloticus and Clarias gariepinus in Ismailia Governorate.
}

Derwa, H.I.M.; Eman, Youssef M.*; Amina, Dessoki A. **; Ali, A.G. *** and Maather, EL-lamie M.

Dept. of Fish Diseases and Management, Fac. of Vet. Med., Suez Canal

University. $\quad *$ Dept. of Parasitology, Fac. of Vet. Med., Suez Canal University. **Dept. of Pathology, Fac. of Vet. Med., Suez Canal University. *** Veterinary Medicine Foundation, Authority of Vet Services, Ismailia.

\begin{abstract}
:
The present study was carried out on 360 of two species of freshwater fishes (200 Oreochromis niloticus and 160 Clarias gariepinus, which were collected randomly and seasonally from different localities in Ismailia governorate from December 2017 to November 2018. Naturally infested fishes revealed no phathognomonic clinical signs except dark coloration and ulcers on skin in $\mathrm{O}$. niloticus and $\mathrm{Cl}$. gariepinus. Postmortem examination showed hemorrhages, abrasions in the skin, presence of yellow cysts embedded in musculature and enlargement of liver with yellowish discoloration in both $O$. niloticus and $C l$. gariepinus. The total infestation rate was $70 \%$; in $\mathrm{O}$. niloticus $(62 \%)$ and in $\mathrm{Cl}$. gariepinus (80\%). The isolated monogenetic trematode was Cichlidogyrus tilapiae from gills of $O$. niloticus. The isolated digenetic trematodes were Orientocradium batrachoides, Astiorema reniferum and Afromacroderoides lazera from the intestine of $\mathrm{Cl}$. gariepinus. Eumesenia aegypticus was isolated from the intestinal lumen of $O$. niloticus, while encysted metacercariae (EMC) were isolated from different organs of infested $O$. niloticus. Confirmation of trematode infestation was done by using molecular diagnosis (PCR). Seasonal distribution and histopathological examinations were also recorded and discussed.
\end{abstract}




\section{INTRODUCTION:}

Egypt has large areas of fresh, brackish and marine water bodies suitable for fishing. Moreover, the climatic conditions are optimum for fish farming, with high growth rates for the fish that are raised, which constitute as a cheap source of animal protein for Egyptians (Ishak et al. 1982). The freshwater fish $O$. niloticus is of high economic value because of its rapid growth rate. It tolerates a wide range of environmental conditions and can be farmed easily (Altun et al., 2006). Cl. gariepinus inhabits in fresh waters which has a great importance for fish farming in Africa due to its wide geographical spread, its resistance to handling and stress, high growth and well appreciated in wide range of African countries (Ikechukwu et al., 2017).

Trematodes are most common parasites of all types of vertebrates and may inhabit as adults, juvenile worms and EMC. Digenean trematodes are considered the largest group of all internal parasites as they include about 18000 nominal species (Kostadinova and Pérez-delOlmo, 2014). Monogeneans are external parasites of fish, which are hermaphrodite with direct life cycle (Valigurová et al., 2011). The aim of this study was to investigate diseases resulting from trematode infestations affecting $O$. niloticus and $\mathrm{Cl}$. gariepinus.

Materials and Methods:

\section{Fishes:}

A total number of 360 freshwater fishes of two species (200 $O$. niloticus and $160 \mathrm{Cl}$. gariepinus) of different body weights and lengths were randomly collected alive and freshly dead from fishermens in Ismailia governorate. They were collected in different seasons between Dec.2017 to Nov. 2018. Both fish species were transported to the Lab of Fish Diseases and Management Department, Faculty of Veterinary Medicine, Suez Canal University. Live fishes were transported in polyethylene bags containing $1 / 3$ of its volume water and $2 / 3$ was filled with air, while the freshly dead samples transported in ice box covered by ice.

\section{Clinical examination:}

Live fishes and dead ones were examined by using magnifying lens for detection of external abnormalities, according to Amlacker (1970). Internal abnormalities were detected according to Lucky (1977).

\section{Parasitological examination:}

\section{1-Macroscopic examination:}

Examination was done by naked eyes and hand lens for detection of external and internal trematodes after fish scarification.

\section{2-Microscopical examinations:}

Gills and gill mucus were examined immediately for detection of monogeneans. They were removed with a fine needle and prepared for slides according to Justine (2005). Skin and fins were examined by 
scraping them with scalped blade from just behind operculum to the tip of the tail. Scales and mucus were transferred to a cover slide with a drop of distilled water to avoid drying and examined microscopically. Small pieces of the internal organs (liver, spleen, kidneys, gonads and heart) and musculature were taken for wet mount preparation and examined under binuclear microscope for detection of EMC. EMC were fixed in formalin solution $5 \%$ for 24 hours then examined under light microscope. Stomach and intestine were scrapped then the parasites were removed with a fine brush and adequately washed in physiological saline and prepared permanently according to Lucky (1977).

Preparation of permanent slides and staining:

A-Monogenetic trematodes:

In a clean petri dish containing physiological saline, gills were placed till monogenea detached then transferred in a clean petri dish and fixed with 5\% formalin for 24 hours , washed in tap water, staining with borax carmine for 5 minutes then washed carefully with tap water. Differentiation occurred in acid alcohol (1 HCL in $70 \%$ ethyl alcohol) using dissecting microscope till reaching appropriate staining then washed with tap water, dehydration occurred by serial grades of ethyl alcohol (30, 50, 70, 80, 90 and 100\%), clearance by using clove oil, xylene for removing excess oil and mounted by using canada balsam then left to dry in a horizontal manner in hot air oven. (Negm El-Din et al., 1995).

\section{B-Digenetic trematodes:}

Digenean adult trematodes which obtained from intestines and stomach were placed into test tubes containing distilled water and with vigorous shaking, worms were washed, relaxed and be ready for fixation by using $5 \%$ neutral buffered formalin for 24 hours, then preserved in vials contain $70 \%$ ethyl alcohol and stained, according to Lucky (1977).

\section{C- EMC:}

Fixed EMC from infested organs and musculature were stained and mounted according to Lucky (1977).

Detection of Orientocradium batrachoides by using PCR:

Samples of DNA were obtained from parasites infested fishes following clearance with SDS $1 \%$. DNA was extracted with QIA amp DNA mini kit (GIAGEN, USA) Ref. No (51304) according to instructions of manufacture. To ensure a good-quality input of DNA, the isolated DNAs were investigated for proper concentration and integrity using agarose running gel assay. To ensure that the isolates were belong to trematode, two sets of universal primers representing variable regions on ITS2 gene were selected according to Arya et al. (2016), and gave amplification bands of 539bp (Table, 1). All PCR amplifications were performed using commercial 
Emerald Amp GT PCR Master mix (Takara) Ref. No (RR310A). In all PCR experiments, DNA from pure cultures of trematode were included as a positive control, whereas molecular biology water was used as negative control. Amplified products were then detected by horizontal $1.5 \%(\mathrm{w} / \mathrm{v})$ agarose gel electrophoresis for $30 \mathrm{~min}$ at $1-5$ volts $/ \mathrm{cm}$. After gel separation, the amplified products were visualized using a Polaroid MP-4 camera and computer digitized (Gel Doc100, Bio-Rad). A 100bp ladder gel Pilot
(QIAGEN, USA) was used as a molecular mass marker.

\section{Histopathological examination:}

Small specimens of the suspected organs (skin, intestine, stomach, ovary, tests, brain, eyes, spleen and kidney) that showed lesions were fixed in $10 \%$ neutral buffered formalin for $48 \mathrm{hrs}$., dehydrated in serial grades of ethyl alcohol (70, 80,90 and $100 \%$ ) for $1 \mathrm{hr}$., prepared and stained with Hematoxylin and Eosin (H\&E) according to Carleton (1976).

Table (1): Primers sequences and amplified segment (bp) of ITS2 gene.

\begin{tabular}{|c|c|c|c|}
\hline \multirow{2}{*}{ Target gene } & Primers sequences & $\begin{array}{c}\text { Amplified } \\
\text { segment } \\
\text { (bp) }\end{array}$ & Reference \\
\hline \multirow{3}{*}{$\begin{array}{c}\text { Trematodes } \\
\text { ITS2 }\end{array}$} & $\begin{array}{c}\text { GGTACCGGTGG } \\
\text { AGTTCTTTTCC }\end{array}$ & \multirow{2}{*}{ GTG } & \multirow{2}{*}{$\begin{array}{c}\text { Arya } \text { et } \\
\text { al., 2016 }\end{array}$} \\
\cline { 2 - 2 } & $\begin{array}{c}\text { GGGATCCTGGT } \\
\text { AGTTCTTTCC } \\
\text { TCCGC }\end{array}$ & & \\
\hline
\end{tabular}


Results:

Clinical examination of the naturally infested fishes:

Most of the naturally infested fishes (O. niloticus and $\mathrm{Cl}$. gariepinus) showed no pathognomonic clinical signs. Some cases of $O$. niloticus revealed hemorrhages on the skin, (Plate 1.a) and cataract were also observed, (Plate 1.b). While in $\mathrm{Cl}$. gariepinus there were hemorrhages on the ventral aspect, (Plate 1.c) and lot of ulcers all over the body, (Plate 1.d).

\section{Postmortem examination:}

Gills of $O$. niloticus showed marbling appearance with excessive mucous secretions with erosions of gill tips, (Plate 2.a). Liver; in infested $O$. niloticus showed enlarged size, (Plate 2.b). Musculature showed yellowish cysts in O. niloticus, (Plate 2.c). Ovaries showed large size and firm nodules in $O$. niloticus, (Plate 2.d). Brain of infested with EMC of $O$. niloticus showed severe congestion, (plate 2.e). Kidneys; in $\mathrm{Cl}$. gariepinus showed yellowish embedded cysts, (plate 2.f)

\section{Parasitological examination:}

A-Monogenetic trematodes:

\section{1-Cichlidogyrus tilapiae:}

The parasite was isolated from the gills of $O$. niloticus, it is a flat worm has two elliptical projections at the anterior end. The posterior end (haptor) has two pairs of anchors and several marginal hooklets. From the morphological and parasitological characteristics, it was related to phylum
Platyhelminthes class Trematoda, order Monogenia, family Ancyrocephalidae and genus Cichlidogyrus, (Plate 3.a).

B-Digenetic trematodes:

\section{1-Eumesenia aegypticus:}

It was isolated from the intestine of $O$. niloticus, it was pyriform in shape, and the cuticle covered with spines. The anterior sucker is a cubshaped. It has two oblique testes situated at the posterior. The ovary is nearly oval in shape. The veteline follicles are clusters situated laterally. From the morphological and parasitological characteristics, it was related to family Maseniidae and genus Eumesenia, (Plate 3.b).

\section{2-Orientocredium batrachoides:}

It was obtained from the intestine of Cl. gariepinus and had a lanceolated body armed with a tiny spine. The testes were large in size may be separated or in contact. The ovary is oval in shape, located near to acetabulum. The uterus was a narrow-coiled tube. From the morphological characteristics, it was related family Orientocreadiidae and genus Orientocredium, (Plate 3.c).

\section{3-Afromacroderoides lazera:}

The parasite was isolated from the intestine of $\mathrm{Cl}$. gariepinus. The worm had elongated body with uniform width. The cuticle was covered with tiny spines. The oral sucker is sub terminal. In front of the ventral sucker there was genital pore. The testes are situated obliquely in the posterior half of the body. The ovary located at the right 
of the mid line. The veteline follicles extend from the ventral sucker to the posterior borders of the anterior testis. From the morphological characteristics, it was related family Afromacroderodium and genus Afromacroderoides, (Plate 3.d).

\section{4-Astiorema reniferum:}

The parasite was isolated from the intestine of $\mathrm{Cl}$. gariepinus. It had elongated body covered with tiny spines. The testes were ovoid in shape and the ovary was squarish. The veteline follicles extended laterally from the acetabulum to behind the posterior testis. From the morphological characteristics, it was related family Opithorchiidae, subfamily Astiotrematinae and genus Astiorema, (Plate 3.e).

\section{5-Unidentified EMC of digenetic trematodes:}

EMC were recovered in different organs like, liver, ovaries, brain, gills and musculature of both $O$. niloticus and $\mathrm{Cl}$. gariepinus. It was circular in shape with double wall; the outer membrane was thick and the inner was thin (Plate, 4).

\section{PCR results:}

The samples were analyzed based on the, trematode ITS2 (internal transcribe spacer gene) PCR products having the sequence (GGT ACC GGT GGA TCA CTC GGC TCG TG) and (GGG ATC CTG GTT AGT TTC TTT TCC TCC GC). PCR amplification and agarose gel electrophoresis expected positive band at $539 \mathrm{bp}$, (Photo, 1) which confirmed that the parasite is a trematode; Orientocredium batrachoides

Histopathological findings of the infested $O$. niloticus and $\mathrm{Cl}$. gariepinus tissues:

\section{A-O. niloticus:}

Multiple EMC embedded between the villus epithelium or between serosa of intestinal wall and musculosa in intestine, (Plate 5.a).

On the other hand, liver showed encysted metacercaria surrounded with a thick fibrous capsule causing atrophy of the surrounding hepatocytes, causing diffuse to multifocal vacuolar degenerations of hepatocytes, (Plate 5.b). Ovary showed massive infestation of the wall and between ovarian follicles with multiple number of encysted metacercariae surrounded by very thick fibrous capsule and adjacent tissues showing atrophy which cause mechanical degeneration, (Plate5.c) Also, brain showed encysted metacercaria embedded in sub-meningeal tissue and surrounded with leukocytic infiltrations, (Plate 5.d).

\section{B- Cl. gariepinus}

The examined liver of the infested $\mathrm{Cl}$. gariepinus showed EMC surrounded with a thick fibrous capsule causing atrophy of the surrounding hepatocytes, (Plate 5.e). Musculature of the infested $\mathrm{Cl}$. gariepinus showed EMC between muscle fibers and causing severe degenerative changes, hyalinization, and edema along with leukocytic infiltrations, (Plate 5.f). 

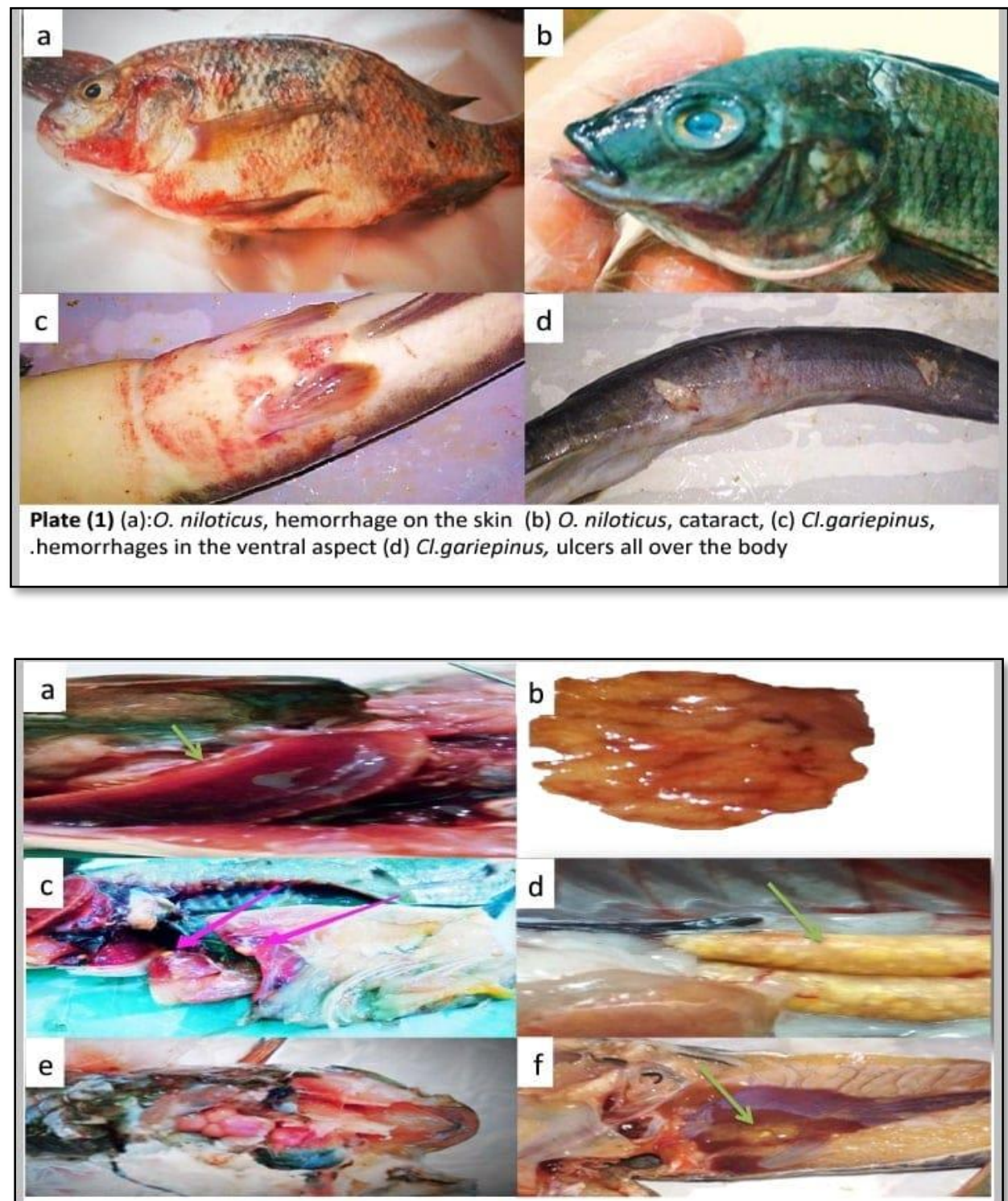

Plate (2) (a):O. niloticus, marbling appearance of gills (b) $O$. niloticus, liver enlargement, (c) $(O$. niloticus, embedded cysts in musculature(d) O. niloticus, ovaries enlargement (e) O.niloticus, .congestion of brain (f)Cl.gariepinus, embedded cyst in kidney 

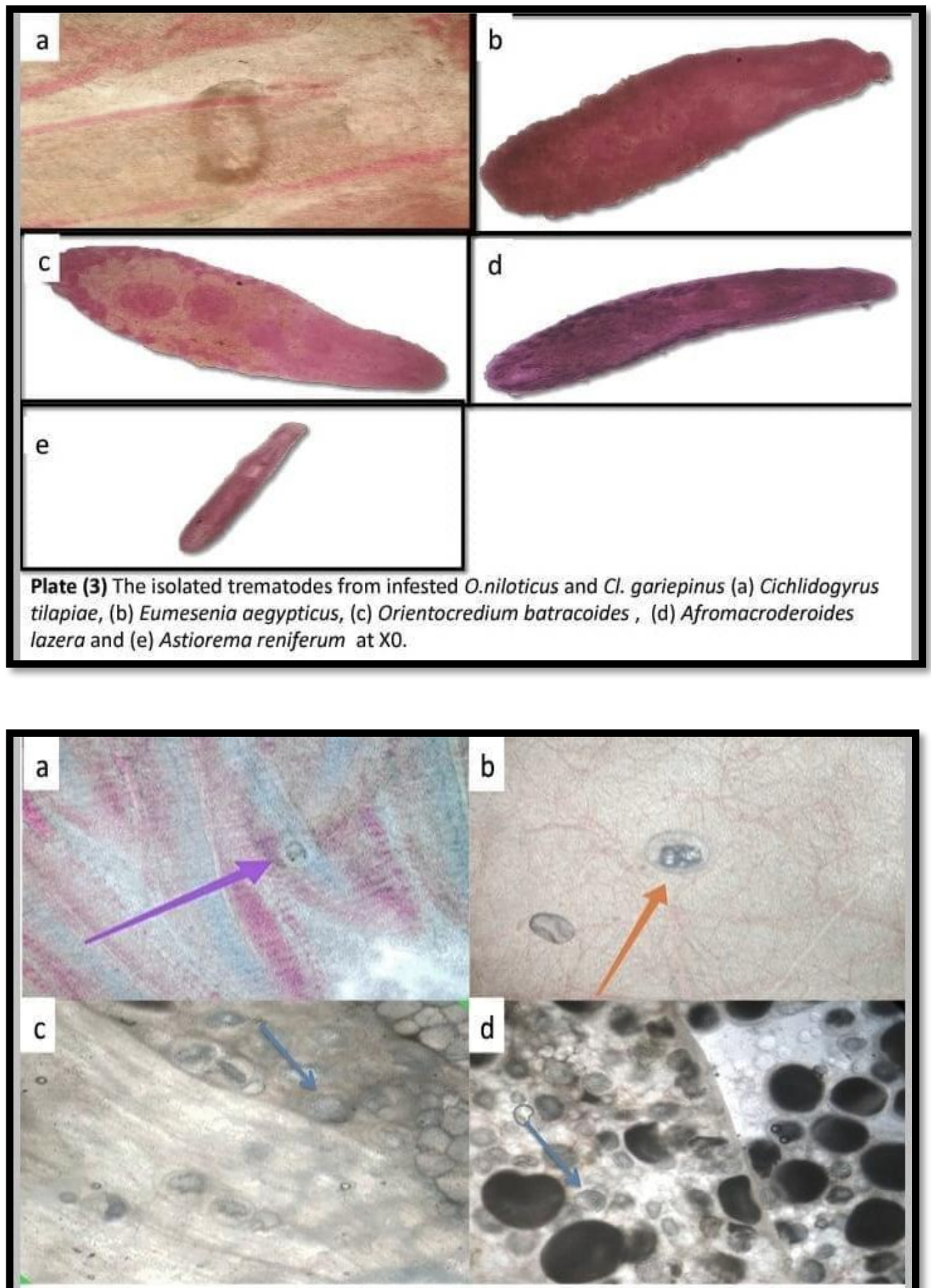

Plate (4) Wet mount preparation of different organs (a) gill tissue, (b) brain tissue, (c) ocular tissue and (d) ovarian tissue of infested $O$.niloticus containing encysted metacercariae. 


\section{Total and seasonal prevalence of trematode disease infestations among} examined fishes:

Table (2) and chart (1) showing the total prevalence of O.niloticus and Cl.gariepinus and table (3) and chart (2) showing the seasonal prevalance of trematode infestation in both of them.

Table (2) prevalence of trematode disease infestations among examined fishes

\begin{tabular}{|l|l|l|l|}
\hline Fish species & No. of examined fish & $\begin{array}{l}\text { No. of } \\
\text { infested fish }\end{array}$ & $\begin{array}{l}\text { Prevalence } \\
\%\end{array}$ \\
\hline O.niloticus & 200 & 124 & 62 \\
\hline Cl.gariepinus & 160 & 128 & 80 \\
\hline Total & 360 & 252 & 70 \\
\hline
\end{tabular}

Chart (1) prevalence of trematode disease infestations among examined fishes

\section{Prevalence \%}

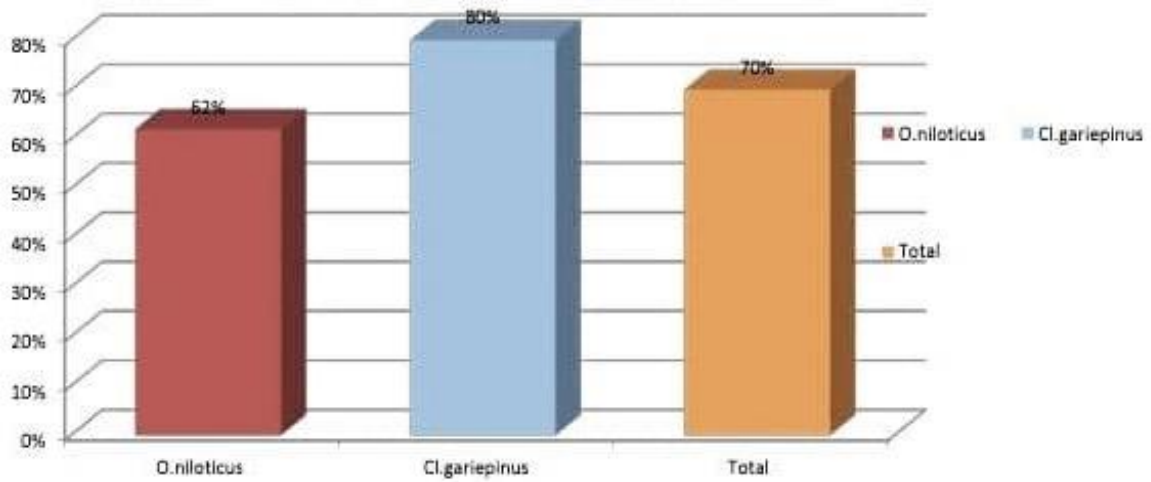


Table (3) Seasonal prevalence of trematodes disease infestations among examined fish species

\begin{tabular}{|l|c|c|c|c|c|c|c|c|}
\hline \multirow{2}{*}{ Fish species } & \multicolumn{9}{|c|}{ Seasonal prevalance } \\
\cline { 2 - 9 } & \multicolumn{2}{|c|}{ winter } & \multicolumn{2}{|c|}{ spring } & \multicolumn{2}{c|}{ summer } & \multicolumn{2}{c|}{ Autumn } \\
\cline { 2 - 9 } & No. & $\%$ & No. & $\%$ & No. & $\%$ & No. & $\%$ \\
\hline $\begin{array}{l}\text { O. } \\
\text { niloticus }\end{array}$ & $\begin{array}{c}35 \\
\text { (N50) }\end{array}$ & $\begin{array}{c}70 \\
\text { (N50) }\end{array}$ & $\begin{array}{c}30 \\
\text { (N50) }\end{array}$ & $\begin{array}{c}60 \\
\text { (N50) }\end{array}$ & $\begin{array}{c}27 \\
\text { (N50) }\end{array}$ & $\begin{array}{c}54 \\
\text { (N50) }\end{array}$ & $\begin{array}{c}20 \\
\text { (N50) }\end{array}$ & $\begin{array}{c}40 \\
\text { (N50) }\end{array}$ \\
\hline $\begin{array}{l}\text { CI. } \\
\text { gariepinus }\end{array}$ & $\begin{array}{c}38 \\
\text { (N40) }\end{array}$ & $\begin{array}{c}95 \\
\text { (N40) }\end{array}$ & $\begin{array}{c}35 \\
\text { (N40) }\end{array}$ & $\begin{array}{c}87.5 \\
\text { (N40) }\end{array}$ & $\begin{array}{c}30 \\
\text { (N40) }\end{array}$ & $\begin{array}{c}75 \\
\text { (N40) }\end{array}$ & $\begin{array}{c}25 \\
\text { (N40) }\end{array}$ & $\begin{array}{c}62.5 \\
\text { (N40) }\end{array}$ \\
\hline
\end{tabular}

Chart (2) Seasonal prevalence of trematodes disease infestations among examined fish species
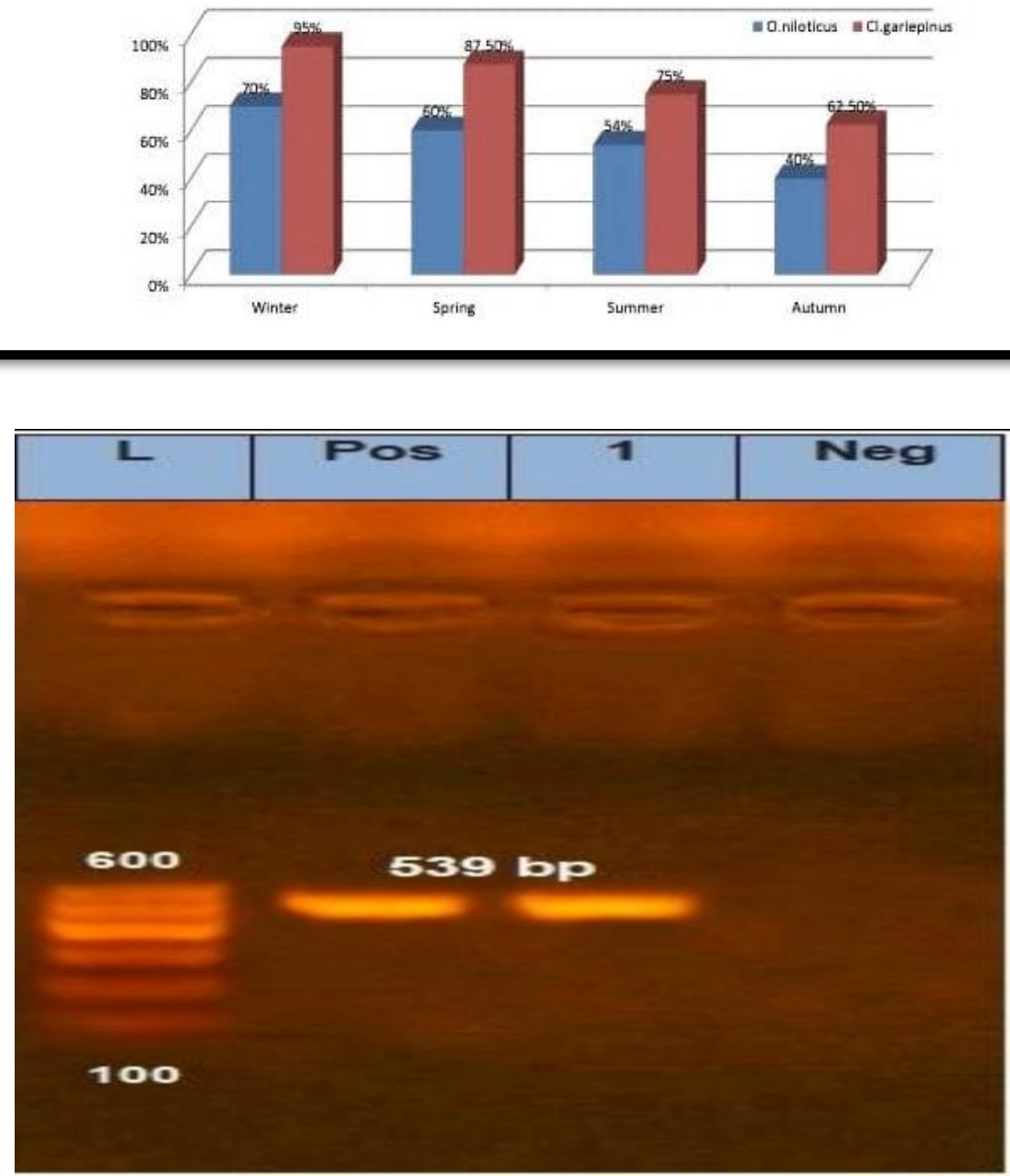

Photo (1): A representative gel displaying analysis of ITS-2 region (internal transcribe spacer gene) from adult trematodes samples. 


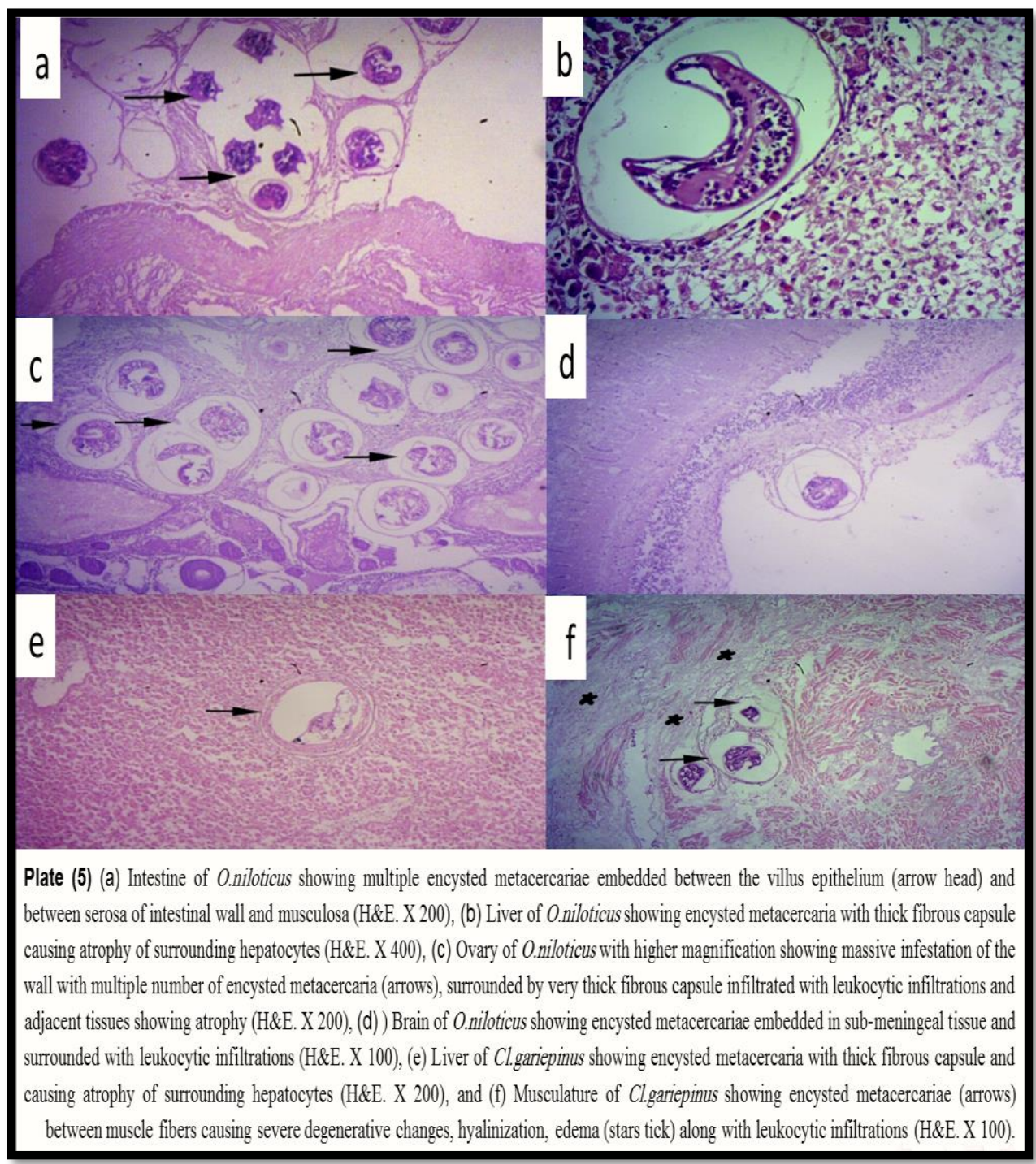

\section{Discussion}

The present study aimed to investigate some of the parasitic diseases (trematodiasis) affecting $O$. niloticus and $\mathrm{Cl}$. gariepinus. The most common clinical signs which detected in naturally infested $O$. niloticus with trematodes were hemorrhages and darking of the skin, erosion of fins and cataract in the ocular tissue. While in $\mathrm{Cl}$. gariepinus there were hemorrhages and ulcers all over the body and frayed fins. Concerning postmortem examination; there were yellwish cysts embedded in different parts of musculature espacially in $O$. niloticus, these results agree with that obtained by Rawia Adawy (2000). Regarding gills of infested $O$. niloticus and $\mathrm{Cl}$. gariepinus, it suffered from excessive mucous secretions leading to severe respiratory manifestations; this may 
be due to feeding activity of the parasite, locomotion and fixation. Concerning mosaic appearance (marbling) of gills, it may be due to penetration of the parasite to the efferent vessels where there is low blood pressure and the hemorrhage are caused followed by a very hard clotting for closing of these vessels, thrombus is occurred leading to ischemia which resulting in necrosis in some areas and congestion of some areas with progressive degeneration of the other parts of the gill filaments giving this appearance. These results agreed with those reported by Eissa (2002). Also, brain suffered from congestion which revealed heavy infestation of $O$. niloticus which may be due to irritation caused by the EMC. Also, liver, kidneys and gonads of Cl.gariepinus were suffered from enlargement. These results were in agreement with that described by Heba Abdel-Moula (2005). Regarding monogenean infestation; the parasite which was isolated from the gills of $O$. niloticus, it was a flat worm, has two elliptical projections at the anterior end .The posterior end (haptor) has two pairs of anchors and several marginal hooklets. According to parasitological examination, the parasite is Cichlidogyrus tilapiae. These results agreed with those reported by Akoll et al. (2012). A fluke isolated from the intestine of $O$. niloticus has pyriform shape; the outer surface (cuticle) was covered with spines. According to the parasitological examination the fluke is Eumesenia aegypticus. This description was similar to that described by Eman Youssef (2001). In this study the parasitological examination of Afromacroderoides lazera which was isolated from the intestine of $\mathrm{Cl}$. gariepinus revealed that the parasite has an elongated body with uniform width, come to a point at the extremities. These findings were with in agreement with that mentioned by Eman Youssef (2001). Another parasite was isolated from the intestine of $C l$. gariepinus and characterized by elongated body, covered with tiny spines and the oral sucker is sub terminal and oval in shape. According to the morphological and parasitological examination, the parasite was Astiorema reniferum. These descriptions come along with that recorded by $\boldsymbol{H e b a} \boldsymbol{A b d} \boldsymbol{E L}$ Moula (2005). In this study, Orientocredium batracoides was obtained from the intestine of $\mathrm{Cl}$. gariepinus. It has a lanceolated body armed with tiny spines and the oral sucker was situated sub terminal. These descriptions agreed to that mentioned by Abbass et al. (2006). EMC which were recovered in different organs (liver, ovary, brain, gills and musculature) were circular in shape with double wall; the outer wall is thick and the inner is thin. These results such as mentioned by Osman (2001). Regarding the total prevalence of infestation in $\mathrm{O}$. niloticus and $\mathrm{Cl}$. 
gariepinus, it was $70 \%$. The total prevalance of infestation in $\mathrm{Cl}$. gariepinus was $80 \%$ and in $O$. niloticus was $62 \%$. The difference may be due to the feeding behavior where $\mathrm{Cl}$. gariepinus is a carnivorous bottom feeder, that feed on low valuable food such as mud, mollusks, arthropods and young infested fish, in addition to they are scaleless fish that permit the penetration of the infective stages through the external body surface. Unlike $O$. niloticus which has shortage period to reach the marketable size in addition to the presence of scales which protect its body from some parasitic infestation. These results were near to that mentioned by $\mathrm{Heba} \mathbf{A b d} \mathbf{E l}$ Moula (2005) who mentioned that the total prevalance of trematodes infestation in $\mathrm{Cl}$. gariepinus was $40 \%$, in cultured $O$. niloticus was $23.27 \%$ and in wild $O$. niloticus was $17 \%$ and Walaa El-Houseiny (2008) who reported that the infestation rate was $96.55 \%$ and $95.83 \%$ in both cultured and wild Cl. gariepinus, respectively. While the rate was $62.32 \%$ and $43.46 \%$ in both cultured and wild sources of Tilapia species, respectively. On the other hand, the results obtained were different from that mentioned by Akoll et al. (2012) who mentioned that the total prevalance of parasitic infestation was 89 and $54 \%$ in $\mathrm{O}$. niloticus and $\mathrm{Cl}$. gariepinus, respectively. These variations may be due to the difference of locations, environmental

conditions, intermediate hosts and final hosts. In the present work, the seasonal distribution was found as, the highest prevalence rates were in winter (70 and 95\%) in O. niloticus and $\mathrm{Cl}$. gariepinus, respectively followed by spring (60 and $87.5 \%$ ) in $O$. niloticus and $\mathrm{Cl}$. gariepinus, respectively followed by summer (54 and 75\%) in O. niloticus and $\mathrm{Cl}$. gariepinus, respectively and the lowest season was autumn (40 and $62.5 \%$ ) in $\mathrm{O}$. niloticus and $\mathrm{Cl}$. gariepinus, respectively. These variations may be due to the difference in seasonal temperature and availability of the intermediate host which increase the feeding activity in these seasons. These results is in agreement with Bassiony (2002) who mentioned that the seasonal infestation rate of enteric trematodes was $(59.37 \%)$ for winter, $(50.58 \%)$ for autumn, $(40.85 \%)$ for spring and $(22.36 \%)$ for summer and Bichi et al. (2010) who mentioned that the highest prevalance of trematodes in $O$. niloticus was in winter $(36.33 \%)$. While our results differ from that obtained by El-Shahawy (2017) who reported that the seasonal prevalance of infestation in $O$. niloticus was high in spring $(61.1 \%)$ then in winter and summer $(33.3 \%)$ then autumn (16.6\%), these variations may be due to differences in locations and environmental conditions. Concerning molecular diagnosis (PCR), the recovered parasites were examined for 
confirming its relation to trematodes which will help in the future for producing vaccines against trematodes and also, in serological analysis by detection the antigen early. The specimens were examined depending on the presence of trematodes ITS2 (internal transcripe spacer gene). The ITS2 gene gives positive bands at $539 \mathrm{bp}$ that confirm that the parasite sample is trematode. These results were similar to that obtained by Arya et al. (2016). In this study the histopathological examination revealed that liver and ovaries of the infested $\mathrm{O}$. niloticus and $\mathrm{Cl}$. gariepinus showing EMC surrounded with a thick fibrous capsule causing atrophy of surrounding hepatocytes and multifocal vacuolar degenerations of hepatocytes, these results were similar to what mentioned by Nouh et al. (2010).

\section{Conclusion:}

Most of the examined fishes $(O$. niloticus and $\mathrm{Cl}$. garipienus) showed no pathognomonic clinical signs, they were apparently normal. Some cases of $O$. niloticus which were heavy infested with trematodes, revealed hemorrhage on the skin and cataract in the ocular tissue was founded. While in $\mathrm{Cl}$. garipienus a lot of ulcers all over the body, hemorrhage on the skin.

$>$ The highest prevalence of infestation was in Cl.gariepinus
(80\%) followed by O.niloticus $(62 \%)$.

$>$ The highest prevalence of trematodes infestation was in winter in O.niloticus and Cl.gariepinus, while the lowest was in autumn.

O.niloticus showed infestation with different worms as Cichlidogyrus tilapiae, Eumesenia aegypticus and Encysted metacercariae. While Cl.gariepinus showed infestation with Orientocredium batracoides, Afromacroderoides lazera, Astiorema reniferum and Encysted metacercariae.

PCR, the most recent method helped in identification of Orientocredium batracoides

\section{References:}

Abbass, A.A., Lashein, G., Tantawy, A., (2006): The prevailing endoparasitic diseases of catfish "Cl. gariepinus" with special reference to the associated pathological changes. Zag. Vet. J., 34: 120-139.

Akoll, P., Konecny, R., Mwanja, W.W., Nattabi, J.K., Agoe, C., Schiemer, F., (2012): Parasite fauna of farmed Nile tilapia (Oreochromis niloticus) and African catfish ( $\mathrm{Cl}$. gariepinus) in Uganda. Parasitology Research, 110: 315-323.

Altun, T., Tekelioğlu, N., Danabaş, D., 2006. Tilapia culture and its problems in Turkey. EUJ 
Fisheries and Aqua. Sci., 23: 473478.

Amlacker, (1970): Text Book Fish Diseases. T.F.H. pubbl., Neature City. New Jerssy 117-135.

Arya, L.K.; Rathinam, S.R.; Lalitha, P.; Kim, U.R.; Ghatani, S. and Tandon, V., (2016): Trematode Fluke Procerovum varium as Cause of Ocular Inflammation in Children, South India. Emerging infectious diseases, 22, (2): 192-200.

Bassiony, A., (2002): Studies on the prevailing internal parasitic diseases among some cultured freshwater fishes in Kafr El-Sheikh Province. MV SC.

Bichi, A., Dawaki, S., 2010. A survey of ectoparasites on the gills, skin and fins of O.niloticusat Bagauda fish farm, Kano, Nigeria. Bayero Journal of Pure and Applied Sciences 3.

Carleton, (1976): "Critical Marine Habitates" in proceedings of an international conferrence on Marine Parks and Reserves, Tokyo, Japan (Pp 45-47).

Eman, Youssef M. (2001). Morphological and clinicopathological studies on the internal parasites of catfishes (Ph.D. Vet. Med. Sc. Dgree (parasitology), Fac. of Vet. Med. Suez Canal University.

Eissa, I.A., 2002. Parasitic Fish Diseases in Egypt. Dar El-Nahda El-Arabia Publishing 32: 149-160.
El-Shahawy, I., El-Seify, M., Metwally, A., Fwaz, M., (2017): Survey on endoparasitic fauna of some commercially important fishes of the River Nile, southern of Egypt (Egypt). Revue De Medecine Veterinaire 168: 126-134.

Heba Abd El-Moula I., (2005): Studies on the enteric parasitic diseases among some cultured and wild fish. Ph. D. Sc. Thesis, Fac. of Vet. Med., Suez Canal University,

Ikechukwu, I., Solomon, R., Wilfred-Ekprikpo, P., (2017): Endoparasites found in $\mathrm{Cl}$. gariepinus (Clariidae) that are found in Kubwa Market.

Ishak, M., et al. (1982). "The utilization of coastal areas for aquaculture development in Egypt."

Justine J. L. (2005): Species of pseudorhabdosynochus

yamaguti,1958 (Monogenia:

Diplectanidae) from Epinephelus fasciatus and E. merra (Perciformes : Serranidae) of New Caledonia and other parts of the indo-Pacific Ocean, with a comparison of measurements of spicemens prepared using different methods and a description of $P$. caledonicus n. sp. Systematic Parasitology, 62 : 1-3.

Kostadinova, A. and A. Pérez-delOlmo (2014): The systematics of the Trematoda. Digenetic Trematodes, Springer, 21-44.

Lucky, Z., (1977): Methods for the diagnosis of fish diseases. Amerind Publishing Co. pvt, Ltd., New 
Delhi, Bombay, Calcutta and New York.

Negm, M.M. and Saleh, G. (1995): Identification and chemotherapeutic control of Monogenetic trematodes affecting Clarias lazera and Tilapia nilotica fishes. Alex. J. Vet. Science; 11(3): 243-262 ( $1^{\text {st }}$ SCVMR).

Osman, A. F. M. (2001): Studies on parasitic gill affections in some cultured freshwater fishes. Vet. Thesis, M. V. Sc. Suez Canal Univ.

Rawia Adawy, S., (2000): Studies on the parasitic diseases of some fresh water fishes in Dakahlia Governorate. Ph. D. Thesis, Fac. Vet. Med., Cairo Univ,
Valigurová, A., Hodová, I., Sonnek, R., Koubková, B., Gelnar, M., (2011): Eudiplozoon nipponicum in focus: monogenean exhibiting a highly specialized adaptation for ectoparasitic lifestyle. Parasitology research 108, 383-394.

\section{Walaa El-Houseiny, (2008):}

Studies on some diseases caused by worms in some fishes. MV Sc.

Thesis, Faculty of Vet. Med.

Zagazig University.

Nouh, Wg, Aly, S., Oh, A., (2010): Histopathological, Parasitological and Molecular Biological Studies on Metacercariae from O. niloticus and Cl.gariepinus Cultured in Egypt, 38, 4, 92-105. 


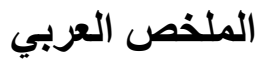

الأمراض الناجمة عن الإصابة بالديدان المفلطحة في اسماك البلطي النيلي والقرموط الافريقي في محافظة الإسماعيلية.

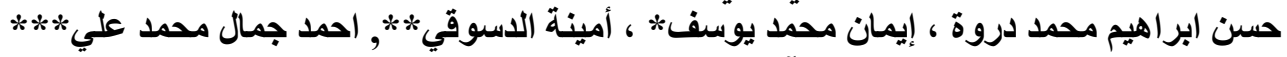

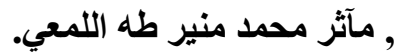

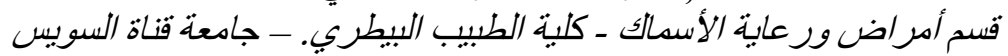

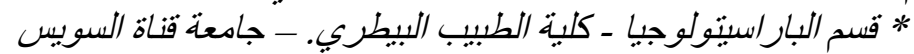

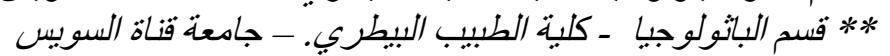

$$
\text { *** مديرية الطب النبيطري - الإسماعيلية. }
$$

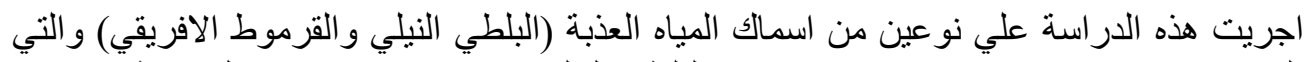

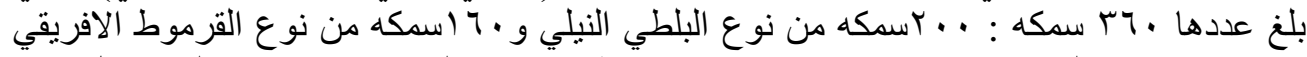

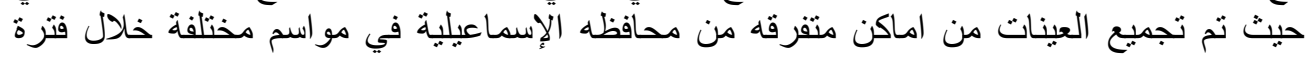

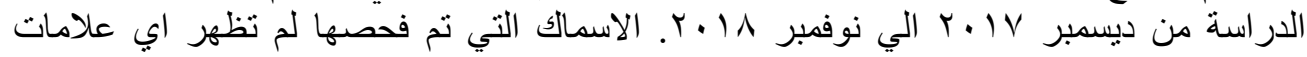

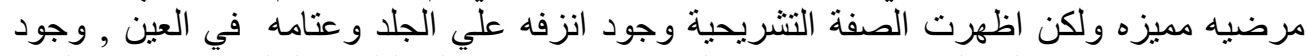

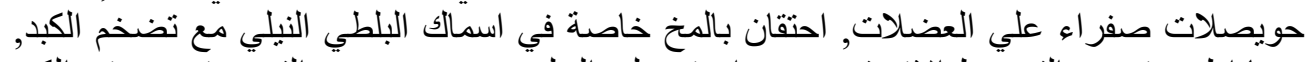

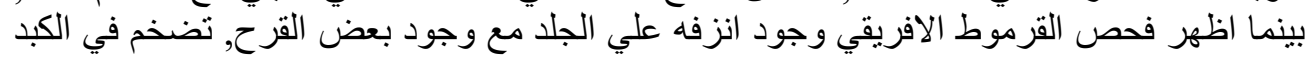

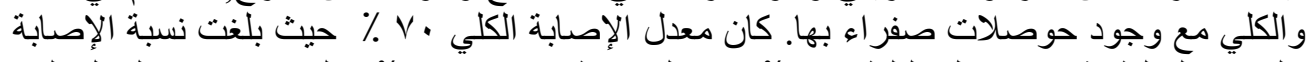

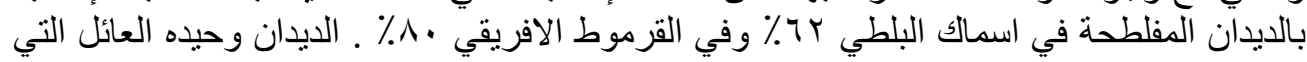

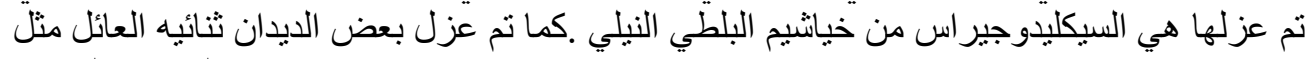

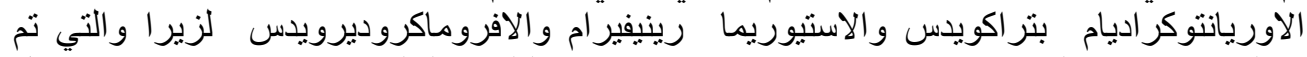

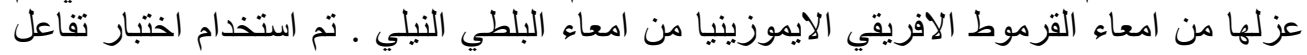

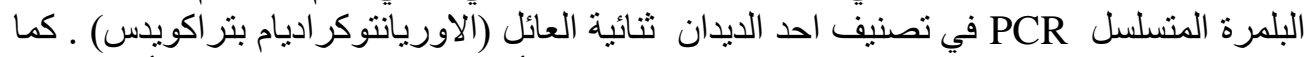

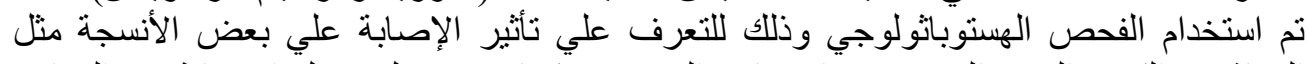

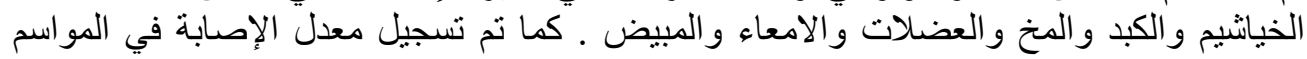

